\title{
The Relationship between Cash Flows and Stock Returns: An Empirical Study of Financial Investment Banks on the Khartoum Stock of Exchange
}

\author{
Sayed Abbas Bala \\ Correspondence: Sayed Abbas Bala, Department of Accounting and Financial. Rajihi Est., Riyadh, KSA. \\ Received: February 20, 2017 \\ doi:10.11114/afa.v3i2.2236 \\ Accepted: March 10, $2017 \quad$ Available online: March 14, 2017 \\ URL: https://doi.org/10.11114/afa.v3i2.2236
}

\begin{abstract}
This study aims to test the relationship between cash flows from operational, investment, and financing activities individually and jointly, and the stock returns of financial investment Banks on the Khartoum stock exchange. Using an analytical approach, the study analyzes the financial statements for 2010-2015. The statistical analysis showed no statistically significant relationship between cash flows from operations, investment, and financing activities individually or jointly, and stock returns of financial investment Banks on the Khartoum Stock Exchange. This study yielded several recommendations such as that the statement of cash flows requires a special awareness because it provides important, quality information that reflects the ability of the firm to meet obligations and function as a going concern, which is useful for users in making decisions.
\end{abstract}

Keywords: cash flows, stock returns, Khartoum stock exchange, cash flows from investment, financial investment banks

\section{Introduction}

\subsection{Introduction to the Problem}

Investment banking includes a group of products and services prepared to meet all financial needs other than ordinary funding requirements instrumental to the performance of companies' typical business activities. Investment Banks provide attractive operational areas for financial intermediaries, consultancy firms, and professionals, due to the high profitability margins (Giovannini, Vincenzo \& Chiesi, 2010).

Investments Banks provide more important services such as advisory services to investors in both private and public sectors, increase companies' financial resources, and create value for firms. In mature capital markets, investment Banks have been assumed to reduce information asymmetry between financial intermediaries and investors. Additionally, the underwriting qualities of investment Banks are not directly observed by investors. Investment Banks, through hard evaluation standards, help to ensure that customers have a positive image about them (Lui \& Zishang, 2016).

In Sudan, there are two financial investment Banks: the Financial Investment Bank and the Al Rowad Bank for Investment and Development. The Financial Investment Bank is a public limited company and the pioneer of financial investment in Sudan. It was incorporated in 1997 and registered on the Khartoum Stock Exchange (KSE) in 1999 to accelerate the KSE, boost financial resources to public and private companies and government corporations via promotion and coverage of public offerings or financing instruments, provide new investment opportunities to individuals or corporations through establishment of investment funds and portfolios for various economic activities, present financial advice to clients and investors in investment in securities and other investment fields, and provide restructuring, merger, acquisition, and privatization services to public and private companies and government corporations (Financial Investment Bank, http://www.fibaonline.com). The financial Investment Bank has an effective role in economic development in Sudan (Ahmed, 2013). As the bank is among the KSE's agents, it plays an active role in raising the KSE's volume of circulation (Abakar, 2007).

Additionally, its role in creating investment funds and benefits a huge number of investors (Osman, 2005). The Financial Investment Bank is the first in Sudan solely mandated to deal with the public sector, financial firms and private and public companies by giving them access to stock exchange services. Its objectives include, among other services, facilitating the establishment of investment funds for individuals or institutions to finance different ranges of economic activities (Malaz, 2014). 
Al Rowad Bank for Investment and Development is a public limited company incorporated in 2013 by converting the Al Rowad Financial Services Company. It began offering all business, investment, and banking and finance activities on July 1, 2013. The bank provides financial investment, investment deposits, and direct financing banking services (http://www.cbos.gov.sd/), (Al Rowad Bank for Investment and Development, Financial statements, 2013) (http://www.kse.com.sd/).

Cash flow values and financial ratios are important in assessing a company's financial position (Khadash \& Abadi 2005). Cash flow is very important to investors for investment decisions. It is significant to determine the cash the firm needs to pay for its obligations, so it is important to test the relationship between cash flows and stock returns of financial investment Banks on the KSE.

\subsection{Importance of the Problem}

The study examines the relationship between cash flows and stock returns of financial investment Banks on the KSE by the answering of the following main questions that reflect the problems considered in the study: What is the relationship between cash flows and stock returns of financial investment Banks on the KSE? This leads to several additional main sub-questions:

1- What is the relationship between cash flows from operations and the stock returns of financial investment Banks on the KSE?

2- What is the relationship between cash flows from investment activities and the stock returns of financial investment Banks on the KSE?

3- What is the relationship between cash flows from financing activities and the stock returns of financial investment Banks on the KSE?

\subsection{Significance of the Study}

The study is significant in that it is the first to address the relationship between the cash flows and returns of investment Banks on the KSE to the knowledge of the researcher. Previous studies have addressed the role and importance of financial investment Banks in the revitalization of the KSE. The results of the present study provide information for users of financial reports, enabling them to rationalize their investment decisions.

\subsection{Objective of the Study}

The main objective of the study is to examine the relationship between the cash flows and the stock returns of financial investment Banks on the KSE and the sub-objectives are to examine the following:

1- The relationship between cash flows from operations and the stock returns of financial investment Banks on the KSE.

2- The relationship between cash flows from investment and the stock returns of financial investment Banks on the KSE.

3) Examining the relationship between cash flows from financing and the stock returns of financial investment Banks on the KSE.

\subsection{Theoretical Framework and Previous Studies}

Financial statements aim to provide financial information about entities that is useful to users in making decisions. These statements do not reflect cash flows as required because based on the accrual basis, users are interested in changes in cash inflows and cash outflows, and the degree of success or failure of operational activities. Accordingly, the International Accounting Standard Board adopted IAS No. (7). (Hardan ,Qabajeh \& Alshanti., 2016). The cash flow statement should be designed to provide confirmation that accrual-based earnings will eventually result in cash flows, as well as to reveal the sources and uses of those cash flows. If accrual-based earnings do not result in cash flows, this information should assist investors and creditors in determining the underlying causes of the disconnect (Deo \& Cathy, 2016).

In order to identify cash inflows and outflows, two methods are presented, direct and indirect method. According to the SFAS 95 or IAS 7, the statement of cash flows prepared under the indirect method (regarding cash flows from operational activities) (Duhovnik, 2008, p 127). Studies (Kew \& Watson. 2006: 10-14) and (Powers \& Needles 2011: 646-648) indicated that cash flow includes three main activities: operational, financing, and investment activities. The operational activities allow estimation of how much cash a firm must have generated from its day-to-day delivery of its products and services. This number can and should be compared with the operating income on the income statement. Financing activity shows whether and how much of the operating and investment activities have been financed by outside sources through debt and equity. The last category is investment activity, which shows the cash flow details of how much cash the firm made and used in investing in other businesses. 
Studies (Khanji \& Siam, 2015) revealed the limited effect of operational, investment, and financing cash flows on the share market value of Jordanian commercial Banks. There is a significant relationship between changes in operating cash flows and changes in stock returns (Kheirandish \& Qeisari, 2014).

Study (Al-saedi 2014) indicated that there is no significant statistical relationship between the cash flows of Iraqi companies and their market value, which means that investors do not consider the cash flow statement when making their investment decision, (Abu-Abbas 2014) showed that we can estimate either the direct method or the indirect method of the statement of cash flows, but the estimated statement does not give completely accurate results. If the users of financial statements accept less than complete accuracy in such statements, then companies can use either an indirect or a direct method for preparing cash flow statements.

Earnings have higher explanatory power than cash flows, although the difference is not statistically significant, and both earnings and cash flows have incremental information content on stock returns (Habib, 2008).

Studies (Durgham \& Durgham's 2010) results indicated the absence of any relationship between shares' returns for all Banks and cash flows from the following: operations, investment, finance, and joint activities other than for the Arab Islamic Bank. The study showed the positive relationship between cash flows from operations, cash from finance activities, and shares' returns, and a negative relationship between cash flows from investment activities and shares' returns.

\subsection{Hypotheses of the Study}

Based on the study's theoretical framework and previous studies, and in accordance with the objectives of the study, the following alternative hypotheses were developed:

The main hypothesis, H. Astatistically significant relationship exists between cash flows from operational, investment, and financing activities and the stock returns of financial investment Banks on the KSE.

The main hypotheses led to the development of the following sub-hypotheses:

Ha- A statistically significant relationship exists between cash flows from operations and the stock returns of financial investment Banks on the KSE.

$\mathrm{Hb}$ - A statistically significant relationship exists between cash flows from investment and the stock returns of financial investment Banks on the KSE.

Hc- A statistically significant relationship exists between cash flows from financing and the stock returns of financial investment Banks on the KSE.

\subsection{The Population of the Study}

The population of the study consists of all financial investment Banks listed on the KSE during the study period from 2010-2015. There are only two such Banks: the Financial Investment Bank and the Al Rowad Bank for Investment and Development. However, the latter was excluded so as not to affect the study because it was incorporated in 2013 and its stock has been subject to merging and exchange during 2010-2015. Additionally, it did not update its published financial statements on the KSE after 2013.

\section{Data Collection Method}

The study reviewed relevant books, research, and published studies in scientific journals and used an analytical approach to analyze the Financial Investment Bank's annual financial reports for 2010-2015 to test the study's hypotheses using the SPSS program and Spearman correlation coefficient.

\section{Data Analysis and Hypotheses Testing}

\subsection{Variables}

1- The dependent variable is Stock Returns (SR).

2- The independent variables are as follows:

a) Cash flow from operational activities (CFO),

b) Cash flow from investment activities (CFI),

c) Cash flow from financing activities (CFF), and

d) Cash flow from operational, investing, and financing activities jointly (CFJ).

\subsection{Variables' Normality Distribution Test}

For variables' normality distribution test, we used a One-Sample Kolmogorov Smirnov test (Table 1). 
Table 1. One-Sample Kolomogorov-Smirnov test

\begin{tabular}{|c|c|c|c|c|}
\hline Sig. & $\mathbf{Z}$ & $\mathbf{N}$ & & Variables \\
\hline $0.200^{\mathrm{c}, \mathrm{d}}$ & 0.230 & 6 & SR & \\
\hline $0.028^{c}$ & 0.341 & 6 & $\mathrm{CFO}$ & \\
\hline $0.200^{\mathrm{c}, \mathrm{d}}$ & 0.223 & 6 & CFI & \\
\hline $0.154^{\mathrm{c}}$ & 0.280 & 6 & $\mathrm{CFF}$ & \\
\hline $0.019^{c}$ & 0.353 & 6 & $\mathrm{CFJ}$ & \\
\hline $0.019^{c}$ & 0.353 & 16 & & all variables \\
\hline
\end{tabular}

Table (1) shows normality test results and that the level of significance for the variables SR, CFI, and CFF is larger than 0.05 which indicates that the data do not follow a normal distribution, and the level of significance of CFO and CFJ is less than 0.05 , which shows that these variables follow a non-normal distribution, which indicates that the study requires the use of nonparametric tests. The study uses Spearman correlation coefficients to test the hypotheses.

\subsection{Testing the First Sub-hypothesis}

Ha: There is a statistically significant relationship between cash flows from operations and the stock returns of financial investment Banks on the KSE.

Table 2. Spearman Correlation Coefficient Results for Hypothesis Ha

\begin{tabular}{lll}
\hline Sig & $\begin{array}{l}\text { Correlation } \\
\text { Coefficient }(\mathrm{r})\end{array}$ & Variable \\
\hline 0.787 & 0.143 & SR \\
& & CFO
\end{tabular}

Table 2 shows the Spearman correlation coefficients between SR and CFO and that the correlation coefficient is not statistically significant at the (sig 0.05 ), the significant is equal to 0.787 , and the value of (r) is equal to 0.143 at degree of freedom of 5, from which we conclude that there is no statistically significant relationship between stock returns and cash flows from operational activities. This is contrary to findings from Kheirandish and Qeisari (2014) .

\subsection{Testing the Second Sub-hypothesis}

$\mathrm{Hb}$ : There is a statistically significant relationship between cash flows from investment and the stock returns of financial investment Banks on the KSE.

Table 3. Spearman Correlation Coefficient Results for Hypothesis $\mathrm{Hb}$

\begin{tabular}{lll}
\hline Sig & $\begin{array}{l}\text { Correlation } \\
\text { Coefficient }(\mathrm{r})\end{array}$ & Variable \\
\hline 0.156 & -0.657 & SR \\
& CFI
\end{tabular}

Table 3 shows the Spearman correlation coefficient between SR and CFI, which shows that the correlation coefficient is not statistically at a significant level (sig. 0.05) the significant is equal to 0.156 , and the value of (r), is equal to - 0.657 at degree of freedom of 5 , from which we conclude that there is no statistically significant relationship between stock returns and cash flows from investment activities.

\subsection{Testing the Third Sub-hypothesis}

Hc: There is a statistically significant relationship between cash flows from financing and the stock returns of financial investment Banks on the KSE.

Table 4. Spearman Correlation Coefficient Results for Hypothesis Hc

\begin{tabular}{lll}
\hline Sig & $\begin{array}{l}\text { Correlation } \\
\text { Coefficient }(\mathrm{r})\end{array}$ & Variable \\
\hline 0.266 & 0.543 & SR \\
CFF
\end{tabular}

Table 4 shows the Spearman correlation coefficient between SR and CFF, which indicates that the correlation coefficient is not statistically at a significant level (sig. 0.05), the significant is equal to 0.266, and the value of(r) is equal to 0.543 , at degree of freedom of 5 , from which we conclude that there is no statistically significant relationship between stock returns and cash flows from financing activities. 


\subsection{Testing the Main Hypothesis}

$\mathrm{H}$. There is a statistically significant relationship between cash flows and the stock returns of financial investment Banks on the KSE.

Table 5. Spearman Correlation Coefficient Results for the main Hypothesis

\begin{tabular}{lll}
\hline Sig & $\begin{array}{l}\text { Correlation } \\
\text { Coefficient }(\mathrm{r})\end{array}$ & Variable \\
\hline 0.872 & -0.086 & SR \\
& & CFJ
\end{tabular}

Table 5 shows that the Spearman correlation coefficient between SR and CFJis not statistically at a significant level (sig. $0.05)$, the significant is equal to 0.872 , and the value of(r) is equal to $(-0,086)$ at degree of freedom of 5 , from which we conclude that there is no statistically significant relationship between stock returns and cash flows from operational, investment, and financing activities. This is the same result as in Al-saedi (2014), though Durgham and Durgham (2010) also showed no relationship, except in the case of one bank.

\section{Results}

According to the theoretical framework, data analysis, and hypotheses testing, the study shows the following results:

1- There is no statistically significant relationship between cash flows from operations and the stock returns of financial investment Banks on the KSE.

2- There is no statistically significant relationship between cash flows from investment activities and the stock returns of financial investment Banks on the KSE.

3- There is no statistically significant relationship between cash flows from financing activities and the stock returns of financial investment Banks on the KSE.

4- There is no statistically significant relationship between cash flows from operations, investment, and financing activities and the stock returns of financial investment Banks on the KSE.

\section{Recommendations}

The results of the study suggest the following recommendations:

1- Review and update the published financial information for financial investment Banks on the KSE regularly, which helps to provide information to investors so that they can rationalize their investment decisions.

2- The statement of cash flows requires a special awareness because it provides important and quality information that reflects the ability of the firm to meet obligations and function as a going concern. This is useful for users in making decisions.

3- Conduct similar studies on several sectors to test the relationship between cash flows and stock returns.

4- Conduct further studies using data on different periods in order to determine the role of cash flow activities in explaining the stock price behavior of financial investment Banks on the KSE.

\section{References}

Abakar, M. I. A. (2007). The role of the financial investment Bank in activation of Khartoum stock market analytical and implementation study For the Period 2001-2005, Master Thesis ,Sudan University of Science and Technology, College of Graduate Studies, Khartoum.

Abu-Abbas, B. M. (2014). Direct, Indirect, or Both Methods of Reporting Operating Statement of Cash Flows, International Journal of Finance and Accounting, 3(6), 335-340.

Ahmed, M. A. (2013). Role of the Financial Investment Bank in economic development on Sudan, Master Thesis, Sudan University of Science and Technology ,College of Graduate Studies, Khartoum

Al Rowad Bank for Investment and Development, 2013. Financial statements: http://www.kse.com.sd//(accessed13.09.2016).

Al-saedi, A. A. (2014). The effect of cash flow on the market value of Iraqi companies listed at Iraq stock, AL-Qadisiya Journal For Administrative and Economic Sciences, 16(1), 137-148.

Central Bank of Sudan: http://www.cbos.gov.sd/node/3203(accessed 12.11.2016).

Deo, P. L., \& Cathy, Z. S. (2016). All cash is not created equal: Detecting fraudulent cash flow, Journal of Forensic and Investigative Accounting, 8(2), special issue. 
Duhovnik, M. (2008). Improvements of the cash-flow statement control function in financial reporting, Journal of Economics and Business, 26(1), 123-150.

Durgham, S. A., \& Durgham,M. M. (2010). The relationship between cash flows and stock returns according to the international Accounting Standards, (7), An applied study on working national Banks in Palestine, Arab Management Journal, 30(2), 45-80.

Financial Investment Bank: http://www.fibaonline.com.(accessed 15.10.2016) Giovannini, Renato, Capizziand, Vincenzo and Chiesi, Gian Marco .(2010). Investment banking services: Ownership structures, financial advisory and Corporate Governance Models, International Journal of Business Administration, 1(1), 49-63. https://papers.ssrn.com/sol3/papers.cfm?abstract_id=1932065

Habib, A. (2008). The role of accruals and cash flows in Explaining security returns: Evidence from New Zealand, Journal of International Accounting, Auditing and Taxation, 17(1), 51-66. https://doi.org/10.1016/j.intaccaudtax.2008.01.003

Hardan, A. S., Qabajeh, M. A., \& Alshanti, A. M. (2016). The preference of direct or indirect methods in preparing the statement of cash flows in decision making: An Academic Perspective, International Journal of Economics and Finance, 2(8), 206-214. https://doi.org/10.5539/ijef.v8n2p206

Kew, J., \& Watson, A. (2006). Financial Accounting an Introduction, 2nd edition, Publish by Oxford University press, Oxford.

Khadash, H., \& Al Abadi, M. I. (2005). Relationship of accountancy return and cash flow on shareholders rights, in the market value per share. Management Science Journal, 32(1), 141-153.

Khanji, I. M., \& Siam, A. Z. (2015). The effect of cash Flow on share price of the Jordanian commercial Banks listed in Amman stock of exchange, International Journal Economics and Finance, 7(5), 109-115. https://doi.org/10.5539/ijef.v7n5p109

Kheirandish, M. R., \& Qeisari, F. (2014). Investigate the relationship between stock returns and operating cash flow and accounting net income in firms listed in Tehran stock exchange, Asian Journal of Research in Banking and Finance, 4(2), 86-100.

Lui, Y. B. (2016). The Investment Bank's Reputation And The Price Of Underwriting Services: Evidence From China, European Scientific Journal, 12(16), 498-508.

Malaz, K. A. H. (2014). Role of investment funds in activating Khartoum stock exchange: The Experience of The financial investment Bank (2004-2013), Master Thesis, Sudan University of Science and Technology, College of Graduate Studies, Khartoum.

Osman, E. M. (2005). Role of financial investment Banks in activation of stock markets, Master Thesis, Sudan University of Science and Technology, College of Graduate Studies, Khartoum.

Powers, M., \& Belverd, E. N. (2011). Financial accounting principles, 11th edition, publish by Cengage Learning, Mason, $\mathrm{OH}$.

\section{Copyrights}

Copyright for this article is retained by the author(s), with first publication rights granted to the journal.

This is an open-access article distributed under the terms and conditions of the Creative Commons Attribution license which permits unrestricted use, distribution, and reproduction in any medium, provided the original work is properly cited. 